\title{
Women Rising against Economic Depression and State Repression: The Nigeria Example
}

\author{
Osewe Emmanuel Akubor, Beatrice Amili Akubor \\ ${ }^{1}$ Assistant Professor Department of History, Humanities, Obafemi Awolowo \\ University, Ile -Ife, Nigeria. \\ ${ }^{2}$ Department of Crop Production and Protection, Faculty of Agriculture, Obafemi \\ Awolowo University, Ile -Ife \\ * Correspondence: \\ Corresponding Author E-mail: oseweakubor@gmail.com
}

\begin{abstract}
Available evidence from history of the Nigerian area shows that women have played very prominent role in socio-economic development in the area. It has also been established that throughout the developing world, they predominantly engage in multiple economic activities that are crucial to the survival of poor household. In the case of Nigeria, they constitute $49 \%$ of the nation's total population and are responsible for the reproduction of the labour force and for producing of $70 \%$ of nation's food supply. This has therefore always placed them at the forefront of struggles to ensure favorable socio-economic and political situation for survival and have as such been victims of state repression in the course of this. The paper therefore seeks to examine the relationship between women, rise against Economic Depression and exploitation and State repression in Nigerian. Data obtained from primary and secondary sources (literature review and content analysis) were deployed to carry out the study with an analytical and narrative historical method.
\end{abstract}

Keywords: Women, Economic Depression, State Repression, Nigeria

\section{Introduction}

Geographically, Nigeria is a country situated in West Africa sharing land borders with the Republic of Benin in the West, Chad and Cameroon in the east, and Niger in the North. In term of human resources, she is considered the most populous country in sub Saharan Africa and ninth most populous country in the misriqiya

The International Journal of African-Egyptian Studies 
world. Nigeria is a country endowed with abundant natural and material resources. The country's 2006 National Census, opines that the country has a population of about 150 million, out of which almost 50\% account for women. Similarly, statistics from The Federal Office of Statistics (2006) reports that 70\% of this women population, reside and work in the rural areas. Scholars have argued that the implication of this figure from the Federal Office of Statistics on the number of women residing and working in the rural area indicates that a larger percentage of Nigerian women largely live in poverty, lacking access to basic education, decent nutrition, adequate health and social services which the development process is supposed to provide. The World Development Indicators puts the population growth for the country (annual \%) at 2.4 while the GNI (current US\$) is 100.7 billion. The GNI per capita, atlas method (current US\$) is 620.00 .

\section{Women, History and Development}

Historians have pointed out that although not much has been written about the role of women in the pre-colonial Nigerian and African society, but the traditional of the various peoples kept records of their activities. Although some scholars have tend to justify this neglect by arguing that women have no place in the society and history, others have however countered this by arguing that at no point in time did the bible or any tradition really relegated women to the background. For example, S Jurie in his work, The Women in the Bible: Their Subordinate Position, Faith and Culture (2016:132-3) opined that the creation of woman from man's rib provides what was absent for his perfect satisfaction. He continued thus:

Following the plan of creation, woman completes man in having him as her. From this fact the narrator skillfully depicts the relation of man and his wife and also concludes to the divine purpose in human marriage. Accordingly, both creation stories affirms, of course in different ways, not only that man and woman is assigned the highest place all all God's creatures, but also that woman was created of the same species as man. This may seem a commonplace to us, but it was important to the author to insist, against contemporary opinion to the contrary, that woman was not an inferior being 
to man. Rather man and woman complement each other in the same human species.

In line with the above, T Falola (1978) argued that the well being of every society is determined by the activeness of the female folks in the day to day running and affairs of the society. This position is based on the argument that, the success of the larger society, depends largely on the success of the home. In the view of the scholar, apart from the fact that they were in total control of the diet, the upkeep of the environment as well as the nursing and rearing of children, some of these women occupied very significant positions in both the religious and political lives of their various communities. Some of these women were priestesses who like their male counterparts played similar roles in worshiping deities (S Johnson, 1921:64-5, E.B Idowu, 1962:CH 2). In the area of peaceful coexistence, T Falola (1978:141) opined that women have in most cases entered into marriage relationship/ties with neigbhouring states in order to cement existing friendship and/or create new ones. In this way, they became very critical instrument in monitoring and influencing foreign policy decisions. In a more specific term, $\mathrm{T}$ Falola (1978:141) wrote:

As an integral part of the palace system, the Oba's wives (Aya Oba or Olori) were in strategic position to hear and spread rumours, to influence major policies of state, especially in matters relating to their own lineages or communities. Many quarters in the town strove to be represented in the palace not only through the palace servants, but also by marriage ties

In politics of the period, the scholar noted thus:

Yoruba women wielded some political influences which differs from one community to another. Though the validity is yet to be ascertained, a few Yoruba women were reputed to have reached the apex of authority as Obas. Ife tradition mentioned for instance, the reign of the tyrannical Ooni Luwo and women are said to have reigned in Akure and Ilesa. There were women chiefs in nearly all the pre-colonial towns, though the importance attached to their offices varied from one kingdom to another;,,,the olori in addition to some women slaves and palace servants were assigned duties

\section{misriqiya}

The International Journal of African-Egyptian Studies 
of much socio-political importance. Women of rank, royal wives and princesses often formed organisations to protect their own interest

In the economic front, women made meaningful contributions in food production especially in the agricultural area and processing of the farm produce. For instance at the dawn of the farming season, although male members of a community do the initial preparation of the land for farming like felling of trees and clearing the land for farming, it was the women folks (wives) coordinating the children who are responsible for doing the larger part of at the sowing, weeding, harvesting and processing of food. Apart from this, they (women) were also engaged in rearing of small animals within or outside the compound. Specifically in the case of Yoruba women of southwest Nigeria, it has been established that they are as hard working as the male folks especially in agricultural. This is because these women are fully involved in clearing of land, root crop production, planting, weeding, harvesting, transportation and processing; just like her Ibo counterpart who clears the land, plant, weed, harvest, transport, process and store the final product (Akubor and Akubor 2018:1-2).

In the area of processing of raw agricultural produce as well as marketing, it has also been established it was considered the duty of the women, wives and daughters. It is therefore not surprising that the pre-colonial palm oil industry in Nigeria witnessed a marked division of labour, with the women doing a large chunk of the work. In most cases, the adult male was responsible for the harvesting of the ripe palm heads. From this point, the women take over the preparation of the palm oil starting with the picking and collecting of the harvested palm nuts. The job of preparing palm oil was really a tedious one, requiring an enormous labour input. The labour requirement was met by the women, their female friends and children in the household. In cases where the quantities of palm fruits to be prepared much, extra labour might be desired. In this situation, the women would mobilise their friend or a communal work group involving a desirable number of relatives / age-group peers. The contractual agreement stipulates how the labour expended would be repaid (Akubor and Akubor 2018:1-2).

It is in line with the above that scholars have argued that women by their sheer psychological, physiological and intellectual make-up, they do perform more than mere complementary roles in the production process (Jekayinfa, 2002). misriqiya

The International Journal of African-Egyptian Studies 
Emphasizing this point a former Secretary of the United Nation Koffi Anan (1998:5), opined thus:

Even in the midst of war, women have kept family life going; they have cared for the sick and wounded; they have fetched water and firewood, grown crops and tended animals. It is an injustice and outrage that women who are the most likely to argue for peace, are also the ones most severely punished in conflicts usually created by men

\section{Women in the Society upto the eve of Colonial rule}

Scholars have argued that the role of defending the society from whatever point was not alien to the Nigerian woman as this was part of the responsibility she hold during the pre-colonial period. For instance both Johnson 1921 and Lombard (1967) argued that those women made sure that their people were not oppressed or in any way deprived of their basic necessity. Lambard ((1967:80), argued that the Dahomean woman constituted that Amazon, which was part of the army and also acted as the King's bodyguard in war and protectors of the palace in peace time. He argued that it was a devices for foiling military plots, and may have had its origin in the large number of women servants who supplied the King's needs.

In a more specific manner, Argyle $(1966: 63-65,87)$ argued that these Amazons were Akhosi, King's wives, of which there were over 8000 each with female slaves, one woman having up to 50 slaves. He further opined that some of them held administrative posts similar to those of men outside the palace. In his view, these women officials acted as intermediaries between their external counterparts, and brought the "inside" and "outside" together before the king. The use of the words inside and outside is well demonstrated in the role the Amazon played in the Dahomean invasion of Abeokuta in 1851 Johnson (1921: , 31). From the account of Johnson, it is clear that in this encounter, the women played very aggressive role during the war which adversely affected the military reputation of the Egba people. This was because when the Amazon stormed the kingdom, scaling the city walls of Abeokuta, the Egba did not know that they were fighting with women. They only discovered this when, in line with their custom, they wanted to send the genitalia and head of the first enemy captured to the king. Realizing this, they became so furious that they had to rally round and forced the misriqiya

The International Journal of African-Egyptian Studies 
invaders to retreat, pursuing them as far as Ishaga, because they did not take kindly the idea of being attacked by women( Johnson 1921:315-6)

In the northern part of Nigeria, history talks about the reign and military prowess of Queen Amina of Zauzau. Amina was born around 1533 in Zaria, a province of today's Nigeria. She was the daughter of Bakwa of Turunku. When Bakwa died in 1566, the crown of Zazzua passed to Amina's younger brother, Karama. Although Bakwa's reign was known for peace and prosperity, Amina chose to hone her military skills from the warriors of the Zazzau military. As a result, she emerged as leader of the Zazzua cavalry. Many accolades, great wealth, and increased power resulted from her numerous military achievements. The mantle of leadership fell on Amina after the death of Karama, who ruled the kingdom for ten years, during which Amina had matured into a fierce warrior and had earned the respect of the Zazzau military and she assumed the reign of the kingdom. Amina led her first military charge a few months after assuming power. For the rest of her 34 year reign, she continued to fight and expand her kingdom to the greatest in history. The objective for initiating so many battles was to make neighbouring rulers her vassal and permit her traders safe passage. In this way, she boosted her kingdom's wealth and power with gold, slaves, and new crops. Because her people were talented metal workers, Amina introduced metal armor, including iron helmets and chain mail, to her army. To her credit, she fortified each of her military camps with an earthen wall. Later, towns and villages sprung up within these protective barriers. The walls became known as Amina's Walls and many of them remain in existence to this day.

Among the Edo people, history tells of the role of the Queen Mothers who till date viewed as instrumental to the protection and well-being of the Oba and, by extension, the kingdom. Indeed, Obas wore carved ivory pendant masks representing the Iyoba during ceremonies designed to rid the kingdom of malevolent spiritual forces. This is based on the role, she played during the 15th century when an ensuing civil war severely compromised Benin's status as a regional power and undermined Benin City's place at the political and cultural center of the kingdom. This was because, exploiting this weakness, the neighboring Igala peoples sent warriors across the Benue River to wrest control of Benin's northern territories.it was said that the defeat of the Igala by Esigie

Misriqiya

The International Journal of African-Egyptian Studies 
leading to the reestablishing the unity and military strength of the kingdom, was based on the role Idia (his mother) played. Thus, Idia received much of the credit for these victories as her political counsel, together with her mystical powers and medicinal knowledge, were viewed as critical elements of Esigie's success on the battlefield. To reward and honor her, Esigie created a new position within the court called the iyoba, or "Queen Mother," which gave her significant political privileges, including a separate residence with its own staff (A Bortolot, 2003:2)

\section{The Changing System in Nigeria and the Rise of Women: The Colonial Tax Fraud}

Available colonial records have often given the impression that after colonial conquest, the first official clash of the regime with women was on the issue of taxation. The picture often pointed by these records is that the women tried to fight against taxation, a system which was alien to the people of the Nigerian area. Literature containing this account tends to give the impression that the women were against a regime that was aimed at making life better for their society, they did not however, give account of the side of women as struggling against colonial economic strangulating policy of taxation. It must be made clear from the onset that while such agitation among women was common in the southern part of the country, the northern area did not experience much of such as a result of the religion of Islam which does not permit $t$ such practice among women (Isichei 1983:493ff). However, it must be noted that this did not mean the total absence of such, as individual women often regarded as rebels by the religious teachings and practitioners) in the northern part had embarked on such despite religious restrictions.in this case one prominent figure in modern Nigeria from the northern part of Nigeria is Hajia Sawaba Gambo, an active and politician. Commenting on the activities of Gambo in Nigeria, Edun Adebiyi (2008:232) wrote:

Hajiyya Sawaba Gambo of Nigeria, and other such select women radicals were deeply committed to politics as means of effecting social change and, specifically, positive change in the position of women;,,,..For this and in her outright commitment to the cause she fought for, she (Hajiyya Sawaba Gambo) came under constant retribution by the ruling authorities in the North. Sawaba Gambo's efforts were remarkable in her defiance of convention to fight for women's rights in a society where patriarchy was misriqiya

The International Journal of African-Egyptian Studies 
reinforced and sanctioned in even more entrenched ways by a ruling ideology based on Islamic principles. Her views of appropriate gender norms were diametrically opposed to those of the Northern Authorities and of their party, the NPC whose views Ahmadu Bello symbolized when he expressed that giving women the vote or such rights would be socially destabilizing and "revolutionary".

It was therefore the effect of religious teachings and practice in what is known as northern Nigeria that killed the spirit of women active participation in the struggle, for fear of being declared deviants.

Extant literature opine that before the conquest of most parts of Africa, the African communities were organised and administered on a communal basis with internal control mechanisms usually administered on a persuasive basis and appealing to the sense of communal belonging. Ifeuko (2011:1) noted that part of the mechanisms for administering such societies, included voluntary contributions to a common purse for meeting communal needs. Voluntary contributions - largely enforced not with a threat of sanction, but with an appeal to the sense of belonging. For example both Tukur M (1990:60), Abdulrazaq, ( 1993) and Oluwaseun O.B () argued that in the northern part of the country, the emirate system was divided into a number of districts headed by 'Hakimi', whose responsibility is that of tax collector. In the South Western area, there were various forms of taxes such as "Isakole" (tax levied on land used by local communities who are normally expected to pay "tribute tax" to the local chief), "Owo-ori" (tax paid by every individual in the community to the government. Thus among the Yoruba state there was also an appeal to the divine and the sense of community for the imposition of taxes. Communities developed a system of annual levies and special contributions collected through the heads of families. These sources provided revenues to the ruler who relied on tributes, tolls and arbitrary levies for their revenues. Record show that in every town, "a proportionate tax was levied on every house, which has to be paid every week or at farthest, fortnight to the (local) king, who transmits it." Three distinct and recognised taxes in Yoruba land were: - Ishakole: which was a kind of universal land rent- Owo ode: a tribute paid by men and women alike, partly in cash and partly in kind. Tax defaulters were usually ordered to leave their land- Owo

misriqiya

The International Journal of African-Egyptian Studies 
Asinghu: consisted of personal service (such as building and repairing of town walls, working on the farm of Chiefs, etc.) together with contributions of food (Ifueko, O.O (2011:4)

In the eastern part some of the form of taxes in this area were "egbu-nkwu" (tax imposed before palm oil is harvested, it is compulsory and there can be no harvest without it), community effort (tax on members of each community for specific purpose, it is also applicable in the Western Area of Nigeria). Tangban O.E (2008:26), pointed out that before 1891 in the Ejaghan area, there existed the Nkan group specifically saddled with the responsibility of collecting individual taxes in cash or in kind for the running of the affairs of the community. It is possible for those who are unable to physically take part in the community work to pay their levy in cowries (form of cash), food as well as palm wine. They were mostly paid in kind and obligatory personal services otherwise known as "tribute taxes". O.O . Ifueko (2011:6), argued that the precolonial society had well laid out structure that ensured the smooth implementation of this and this included the following

$>$ Collection was done on a communal basis to meet local needs, which could be easily identified;

$>$ The use to which the collections were put were easily verifiable and cases of abuse or misuse of such collections were largely non-existent;

$>$ Collection was made by persons with a moral or religious authority to do so, such authority being one given by the community and not forcefully arrogated;

> Societies were organized in small groupings which made collection easy; and

$>$ Collections were made on basis freely agreed by all members of the community and not imposed by an outside authority (Ifueko, O.O (2011:6).

Scholars are thus of the view that expansion and interaction with foreigners began to alter means of enforcing such contributions - use of sanctions, ostracisation and force were introduced. These systems evolved until the time of complete conquest and colonial rule, where formal systems of taxation were imposed and the basis for enforcement changed from a largely persuasive to a coercive one. This was the situation in Eastern Nigeria which was the major reason for the 1929 misriqiya

The International Journal of African-Egyptian Studies 
Aba Women's Riot, in which women took the led to liberate their husbands and the entire society was the shackle of obnoxious colonial tax system (Emrerenu E, 2015:7).

\section{The Aba, Opobo, Abak and Utu-Etim-Ekpo Women Liberation Struggle and Police Brutality}

Available colonial records show that as a way of easing the burden of their husbands the women had embarked on peaceful protest to colonial offices around their areas. In the case of Opobo, there was discontent caused by the direct taxation of men; the widespread discontent at the persecution, extortion and corruption practices by the Warrant chiefs or Native Court Members; and the low prices ruling for produce and the high prices of imported goods. Apart from the unpopularity of direct taxation anywhere, it was alleged that the incidence was too high; that the number of taxable males was in some towns over estimated; that men had to pawn themselves or their children to pay the tax; and that there had been general distrust of the government with regard to the disposition of the tax. According to the Report of a Commission of Inquiry appointed to Inquire into certain Incidents at Opobo, Abak and Utu-Etim-Ekpo( 1929), it was specifically stated that the grievance of the women and stated they demands thus:

Their demands included non-taxation of women and even of men, no counting of personal property, free licenses for holding plays and the deposition of Chief Mark Pepple Jaja, whom as a member of the Legislative Council, they apparently regarded as a supporter of the Government. In response to this, the women were brutally dealt with using state security and related apparatus.

Although the report argued that the women embarked on peaceful protests, however, they were fired at by the colonial police. For example, in the case of Opobo, It was argued that the women were fired upon because they feared they would proceeds to extremities and that the police or even soldiers would be over powered and the well-stocked factories would be at their mercy. The report puts it thus;

misriqiya

The International Journal of African-Egyptian Studies 
The wearing of fronds of palm leaves by the women ( an emblem according to native custom, both of solidarity and of warlike intent), the convergence of numerous parties from different localities at the one place on the same day and approximately at the same hour, the cheers with which new arrivals were greeted, the absence of children, the arrogance and confidence of the crowds and the arrival of men armed with machetes (cutlasses) just before the attack took place, leave little or no doubt in our minds that the crowds assembled in accordance with a pre-concerted plan and that the women were encouraged, if not instigated, by their men folk, for it is well known to be contrary to native custom for a woman to leave her own village on any unusual venture without the sanction of the husband (Article 4)

On the reason, for shooting at the harmless women, the report continued:

To sum the matter up we are satisfied (a) That the firing at the time it took place was absolutely necessary in order to protect life and property, (b), that it was done with reasonable caution, (c), That it produced no further injury than was absolutely necessary for the prevention of felonious outrage. .. We have no doubt that had the troops been overpowered, the Government offices would have been destroyed and the factories looted. The latter held large stocks of gin and other intoxicants, and had the savage passions of the mob become further inflamed by alcohol, it need hardly be said that the lives of the Europeans in the station, which includes three ladies, would have been in the gravest danger. Indeed it is difficult to see how they could have escaped destruction

Available document indicates that although, the procession was largely made up of women and children, they were treated as threat. For example, for this task (in the case of Opobo) over thirty two police men were engaged, during which shots were fired at over 400 women. In the case of Opobo, the report clearly exposed the fact that it was one Lieutenant Hill who released the first shot with his revolver which killed the first woman, while his orderly and three men round him fired on their initiative, and the section Commander gave the order to fire at the end of which 62 shots were fired, thirty one women and one man lost their lives, and misriqiya

The International Journal of African-Egyptian Studies 
thirty one women were wounded(CO 583Calabar and Owerri Province, 1929). To make sure the people were further intimidated, the town of Azumini was ordered to pay a deposit of $£ 2,000$ within 48 hours. Apart from the burning it was also made clear that the properties of the locals were looted. For instance, Paragraph 391 of the report contained thus:

Chief Onumaebu's house at Ameke was burnt by Lieutenant Sainthill on the District Officer's authority, and this was justified as a means of pressure, but unfortunately the Lieutenant, with Captain Hill's approval, appropriated to his own use some trifling objects found in the house, and does not seem to have realized the impropriety of the proceeding

At Utu Etim Ekpo, the troops indulge in indiscriminate burning; as in the case of two of the houses, the bodies of two of the women killed in the disturbance were burnt. It was also discovered that three women were killed, or died of wounds and another was slightly injured. In the case of Ikot Ekpene, at a certain village sixteen women were killed or died of wounds, a number of others bring wounded, certain compounds were burnt and this included the burning of the substantial property of Ofon Ekpo, whose shop roof was perforated by bullets.

This marked the first stage of brutality against women in the course of struggling for the establishment of a just and fair society, which will recognize them as major stake holders

\section{The Case of the Yoruba Women in Southwestern Nigeria: The Abeokuta Women Revolt}

Available document has shown that women in the southwestern part of Nigeria have in one away or the order been economically repressed and have risen to the task of liberation, but not without state repression and brutality. This was the case of the Abeokuta women under the leadership of Madam Kuti (Mcalpine M, 2013). Although Abeokuta was an ancient settlement, however but by 1914, it was gradually being incorporated into the colonial state. This introduced the area and people into the colonial taxing system especially the imposed sanitary fines, which largely affected farm and market women ((Byfield, J, 2003). Eventually, the fines were abolished and replaced by taxes on women. Thus from 1 January misriqiya

The International Journal of African-Egyptian Studies 
1918, Abeokuta residents began paying taxes. From the tax proposal's inception, Egba women were considered separately from the men. This colonial tax was considered as unfair practice that predominantly targeted women. Six months after the imposition of the tax, a revolt occurred in Abeokuta known as the Adubi War. The revolt consisted of thirty thousand rebels destroying much of the railway and telegraphs lines south of Abeokuta along with the murder of a European trading agent and a high-ranking Egba chief .The insistence of the colonial government to continue the tax despite this protest led to a situation that by the late 1940s, the burden of the taxation was becoming unbearable on the people. It was this that led to the emergence of the Abeokuta Women's Union (AWU) under the leadership of a headteacher of a local school, Funmilayo Ransome Kuti, who had head of the struggles of the market women (Olusola, A, 2013). The AWU, was able to unite the working class market woman and the middle class women, in the struggle to challenge both colonial rule and the patriarchal structure (Mcalpine M, 2013). The women of the AWU were effective organizers, who fought against the colonial government, with different types of resistance tactics. Many women refused to pay the tax and either ended up in jail or fined (Johnson-Odim et al, 1997)

In order to end the taxation regime, the AWU wrote "proposals to replace the flat rate tax on women, on with taxation on expatriate companies, investment in local initiatives and infrastructure including transportation, sanitation and education and the abolition of the Sole Native Authority and its replacement with a representative form of government, including women. The women of the AWU were effective organizers, who fought against the colonial government, with different types of resistance tactics. Many women refused to pay the tax and either ended up in jail or fined. This did not in any way deter the women and their agitation, as they continually sent out several petitions to the Alake between August 1946 and May 1947. The insistence on the government on the continuation of the insensitive taxing system led to a situation in which on 8 December, 1948, over ten thousand women camped outside the palace of the Alake, refusing to leave until all the women who had been arrested were released. This resulted in the release of the incarcerated women two days later. Even after this, the AWU continued to send their petitions to the British administration and eventually they claimed victory. On 3 January 1949, the Alake abdicated from

mistiqiya

The International Journal of African-Egyptian Studies 
the throne and the Sole Native Authority (SNA) system was changed and four women had positions in the new system of administration. The Abeokuta Women's Union had won a great victory in colonial Nigeria but they did not stop there. The women continued to advocate for women's rights in Nigeria and play a role in Nigerian nationalist movements.

\section{Women and Police Brutality in Post -Colonial Nigerian state: the Niger Delta area Example}

Despite the roles played by women in the struggle against economic oppression, liberation struggle and the eventual attainment of independence by the Nigerian state, the Post-Colonial Nigeria state has not reciprocated this gesture in term of opportunities for them. Instead, the women folks have continued to experience economic repression and state brutality in their quest to contribute to national development. This is evident in the laws of the land which forbids them from some basic rights like inheritance and land ownership and well as occupying political positions in states where they are married.

For instance, Apart from the 1978 Land Use Act of Nigeria established a state owned land system that allowed similar opportunity for men and women to acquire or inherit land. However only legally married women could benefit from this act, so it did not necessarily improve the ownership of inheritance rights for women in Nigeria (https//www.landesa.org). This completely relegate to the background the women folks, yet they are expected to fulfill certain financial obligations to the state as well as contribute to economic development. In his analysis, Izehi Oriaghan(2018) wrote:

Land acquisition for men and women in Nigeria, for the most part, is through inheritance. And inheritance rights to a great extent are influenced by the prevailing customs and norms in different parts of the country. Most often, men have a greater chance of inheriting land over women, a patrilineal system of land inheritance that persists despite the provisions of the law. Hence, there is a huge gender gap in land ownership in Nigeria, and less than $2 \%$ of women, compared to $17 \%$ of men, own land by themselves.

misriqiya

The International Journal of African-Egyptian Studies 
The scholar argued further thus:

The 1978 Land Use Act of Nigeria established a state-owned land system that allowed similar opportunities for men and women to acquire or inherit land. However, only legally married women could benefit from this act, so it did not necessarily improve the ownership or inheritance rights for women in Nigeria. Transfer of land ownership is still largely guided by customary practices that discriminate against women, especially because the average citizen has poor knowledge of the statutory laws with respect to land.

The above is more evident in the struggle against economic deprivation and environmental degradation in the Niger Delta area of Nigeria by the women. In their attempt to cater for their families, these women have for long exposed to all forms of brutality and dehumanizing situations in the hands of the state. Over the years, the exploration and exploitation of oil resources in the Niger Delta has resulted in particular economic and environmental conflicts, with the female folks bearing the brunt of the situation. This is because in the area the women are the one engaged in the real production of the means of livelihood through farming while the men are known to always go in pursuit of oil contracts. However, over the years, the pollution caused by both the forceful taking away of farmlands from the women, oil spillage and gas flaring have led to situation in which crop yields have greatly declined. These lands have been used for laying oil pipelines which criss-cross the land and contaminate it. With this situation there is acute shortage in arable land for agriculture, hence the attendant food shortage. The direct impact is that it has led to situation within the region where the already impoverish women must import food from other parts of the country leading to high cost of food. It is also worthy of note that despite the agony of these women, $90 \%$ of them still rely on the use of other crude implements like cutlasses, hoes, knives to carry out their farming activities.(African 2002). This has led to a situation in which the Human Rights Violations Investigation Commission Report, 2000:45$46,84)$ noted thus:

Oil, one of the greatest blessings God has showered on our nations has turned out to be a curse. Instead of providing the basis for national economic, political, scientific / technological and social growth and misriqiya

The International Journal of African-Egyptian Studies 
development, cushioning its citizens from the scourge of abject poverty, squalor and want, oil became, in the hands of the ruling elite and the political class, an instrument sounding the death knell of such key principles of good governance, as democracy, federalism, transparency, accountability and national growth. Oil was the mainstay of the economy and the junta saw any inhibition to its flow as a breach to security. The oil boom became an albatross, a national curse, becoming in due course "the oil doom". The economy experienced neglect of agriculture and other sectors of the economy, indiscriminate, even reckless importation of consumer goods, huge import bill, production and service bottleneck, scarcity and inflation.

The situation of women in this area is a very pathetic one, because apart from the fact they they are the bread winnings, the men (husbands) would prefer to marry more than one wives without making provision for their upkeep. And anytime spillage occur destroying economic crops, it is the women that are worst affected. At the end of the day, these women are not compensated rather any move to get justice leads to situation in which women in the area were subjected to all kinds of violence, sexual violence such as rape, physical violence such as beatings, maiming and murder, as well as destruction of their properties. They have suffered unimaginable human right abuses for which redress is unattainable because their husbands and sons have been killed or maimed in the conflict and women have had to assume burdensome responsibilities as heads of households. To this they have not been able to respond with violence like their male counterparts (Onduku 2004, Azubuike 2008).

The voices of the women have been drowned by the power of the state and their multinational oil allies using force and brutal power. It is important to noted that at various times these women have tendered their displeasure over their dispossession in civil manners, but the response have always been brutal and in some cases ignored. For instance, there was the Ogharefe Women massive nonviolent protest by women from several communities in the Niger Delta in 1984 against US Pan Ocean. The tactics and determination of the women forced the chevron oil company to send their representatives to negotiate with the women. During the negotiation, the women made clear their position, in which they ask the oil companies to make concrete efforts at improving the economic, 
environment and social conditions of the people. Despite this presentation, uptill the 2010's no concrete attempt was made by the oil companies to address the issues table by the women and they ignored the Memorandum of Understanding signed during the parley.

In the case of Pan Ocean, the company bluntly refused to pay the people any compensation, despite the series of protest carried out by the Women between 1984 and 1986. This was also the case of Shell in 1999, which refused to compensate the community despite the protest both in Nigeria and in London particularly against gas flaring. These indeed are glaring manifestation of the rights of the women and outright denial of compensation for taking the source of livelihood and the destruction of the environment. This has in adverse, relegating women in the area to the background despite the immense contribution to the economy of the area especially in the area of food production (Power, 2006). This position of subordination, lack of opportunities as well as their exclusion from decision making make them more vulnerable to poverty; this is apart from the fact that most of these companies have refuse to offer them employment in the firms. Apart from this humiliation, those often sent to keep peace in the area in time of conflict, treat the women as spoils of war, raping them and looting their properties. (Azubuike 2008)

This situation has created a large commercial sex market in the region with all the associated health and social problems. It is in the Niger Delta region that the country is the recording one of the highest level of HIV/AIDS. The presence of the effluent oil workers in the mist of such poverty in the region has led to high rate of prostitution. This had earlier been observed by earlier European visitors to the area in the early 1900. For example, the Benin Province report as documented in Akubor, (2005) captured it thus,

"the companies policies which destroyed the family cohesion among the peasants forcing them to seek cash paying jobs, led to massive migration of the physically fit individuals to the nearest urban centres to seek their fortune....the female members of this group constitute naissance to the community and environs...this was because most of them were forced into prostitution, since they were never able to get occasional jobs like the men ... this group of people were greatly patronised by young men, who misriqiya

The International Journal of African-Egyptian Studies 
worked in the foreign firms... a lot of them go about the camps and towns ..begging for money...they seduced them to buy them wearing apparels and trinkets"

However, Thomas (2003), captured it in another dimension when he contended that the multinational oil workers have often been very brutal to the women, behaving like animals as they take advantage of the poor hungry illiterate girls of the Niger Delta by making them victims of their lust forcefully. These girls according to the scholar inhabit in creeks and villages separated by rivers and seas and had little contact with the outside world. (This he argued is due to devastation caused by the crises in the area as well as the denial of these areas access to basic social amenities and marginalization by the federal government, multinational oil companies and some time leaders from such areas). Thomas further testified they the living conditions of these women and young girls is akin to Stone Age, due to their poor living conditions, thus making them fall victims to these men. At the end of their search and exploitation for oil, these workers leave the women behind with no contact address. They leave behind young unemployed mothers and the kids.

The activities of these explorers is not restricted themselves to only single ladies/ girls. The biting poverty in these communities has forced some married women to respond positively to their lusty demands. At the end these women who think they have found a solution to their problems realize later that they have made it worse (Akoda 2008). Closely related to this is the fact that, the women of this area have suddenly become articles of trade in the hands of both the foreign workers and those who promise to make life better for them outside the crises area. This has resulted in human trafficking in which most women and girls from the area have been sold out for the purpose of prostitution, which is a form of modern slavery. For instance in 2002, 15000, Nigerian women and girls were engaged in prostitution in Italy alone, while countless more were going about in Nigeria. In fact $95 \%$ of these numbers were from the Niger Delta area alone (JDP/Caritas Nigeria, 2008). Analysis shows that in Edo state alone, over 150 families have been traced so far and contacts between them and their daughters for those still in their destination countries have been established 
The above according to Digifa (2008), has led to more instability in the area as the women are gradually becoming militant in their quest for succour. Examples of these almost militant action includes the Ogharefe Women Protest in 1984, Ekpan's Women's Uprising in 1986, the Okutukutu and Etegwe Women Protest in November 1991 due to over flooding of their farm lands cause Gbaran link in Yenagoa, the Obunagha community protest in 1992 due to lack of social responsibility by shell while drilling Gbarana I ( the demands of the women in this case include clean environment, conducive for survival, jobs for their children, safe drinking water, hospital, pollution of rivers and creeks low farm yields, no fishes and crawfish) and the Escravos Episode in which about 600 women (age 30 to 90 ) held 700 Chevron Texaco workers at the Escravos terminal in July, 14, 2002 among others.

According to Ogbogbo (2005) the above issues raised by the women is clear indication that oil production and the related crises which is the most crucial factor in Nigeria has impacted beyond endurance on the people of the Niger Delta. It is the consequence of the intense pollution of the Niger Delta on the economy of the people and their general standard of life that has given birth to the phenomenon which is general known as the Niger Delta crisis (Ajaero 2008).

It is however unfortunate that instead of a more civilized way of addressing these issues raised by the women, the government and the oil companies on the one hand and the militants on the other, have continued to brutalise the women folks, as illustrated by the catalogue below.

On August 8, 2002, over a thousand women from Ijaw, Illaje, and Itshekiri groups held peaceful protest over environmental degradation by oil companies, lack of amenities and allege violation of compensation agreement by S. P. D. C Warri. At the end of the day, about 800 women sustained injures when the police attempted to disperse forcefully.

A year later (specifically on $15^{\text {th }}$ January 2003), indigenes of Ohoror-Uweru community, Ugheli North Local council of Delta state were attacked by a detachment of solders from J. T. F 'Operation Restore Hope. This included women who were in the majority. The same year, it was women that protested at Iri, Isoko South council when a traditional rule was alleged to have sold the rights misriqiya

The International Journal of African-Egyptian Studies 
of the community to Agip Oil. Although peaceful, no fewer than 10 Women were killed. This led to a situation in which properties worth millions of naira were destroyed

In January 2004, Suspected Itshekiri militants invaded some communities in Okpe Kingdom killing 17 people and injuring three others. Nine months later,(in October 2004), Ke and Ijaw communities in Rivers State were attacked by unidentified group and houses and properties running into millions of naira were destroyed. According to the news, those most affected were women, who were either raped or maimed to death. (The Punch October 5, 2004).For several hours, youths of Igbudu and soldiers of the JTF clashed in Igbudu area of Warri. This led to loss of lives of women and properties. Some twenty days later,(on November 22, 2004) 12 persons including women were shot and injured in a clash between youths of Ojobo oil community in Burutu LGA, Delta state and soldiers of the J. T. F deployed to guard the Benideide flow station operated by S. P. D. C. The youths were protesting alleged marginalization and violation of MOU by the company.

On December 23, 2004: Over a hundred houses were ransacked, women raped and property running into millions of naira destroyed when youths in OgbeOsewa and Ogbe-Illo quarters in Asaba clashed.

On February 3, 2005: 12 people including four councillors and a pregnant woman, travailing to Obioku on a peace keeping mission were killed when gunmen attacked their boat on Akananga River in Neme Axis of Bayelsa East senatorial District.

On February 12, 2005: Federal tropes from J. T. F invaded the coasted town of Odioma leaving about 80 persons dead and no fewer than 78 houses, nine mausoleums and other historic relics in ruins. The troops were invited by Bayelsa state Governor, Chief D. S. P Alamieyeseigha to fish out alleged killers of four councilors, a pregnant woman and seven others on February 3, 2005.

On January $5^{\text {th }}, 2008$, Ogochukwu Orisa Onyiri was kidnapped and a ransome of fifty million naira demanded.In June, Augustina Ekeowei, was kidnapped and a ransome of seven million naira was demanded. On July $3^{\text {rd }} 2008$, Folake Coker misriqiya

The International Journal of African-Egyptian Studies 
was abducted, although a ransom of fifty million naira was demanded, she was later found in Ghana. Other related cases includes the kidnapping of Adaobi Nnenna Eze, demanding three million naira ransom; Mrs Meg Idisi, abducted from her family house, while demanding one billion naira for her release, Mrs Goldcoast Dickson, Mrs Seinye Lulu Briggs, Miss Margaret Hill, Franca and Francisca Ehilemi among others( Asoye 2008).

On August 4, 2008: The Joint Task Force invaded Agge in Bayelsa State destroying over 300 homes. In most of these houses women were killed (The News, August, $11^{\text {th }}$ 2003). In September 2008, in a Joint Task Force raid of Yenogoa/ Torugbene- Lobia town bound transport speed boat, 12 passengers were killed including a pregnant woman.

In most of these confrontations the state had acted with force, deploying military men and weapons to maintain the peace. For instance, the confrontation of May 14,2009, the government deployed sophisticated weaponry against the hapless resident of Gbaramatu Kingdon made up of 163 communities. The weaponry deployed to the area included four helicopter gunboats for aerial bombing, two Naval ships; NNS Obula and NNS Nwanba and a large troop of soldiers. In the case of the Odi attack, it was reported that close to 2,873 civilians lost their lives, majority of them women and children (Ogege 2007)

\section{Women and the Girl Child in Nigeria under Democratic Rule: Any Hope}

Scholars have argued that even with the return to democratic rule in Nigeria, and with the much cry against women repression and deprivation, the lots of women in Nigeria has not changed for the better. Instead they are disproportionately represented among the poor household and poverty is being increasingly in the feminized. This is more in the cases of the rural women who play essential roles in crop production and livestock care, provide the food, water, and fuel their family needs. These women make up $49 \%$ of the nation's total population and are also responsible for the reproduction of the labour force of the nation. It has also been established that they produce $70 \%$ of the nation's food supply, yet no recognition or specific training is reserved for her development by the society. For instance, Forty per cent of Nigerian children aged 6-11 do not attend any primary school, and it is northern Nigeria that has the worst school attendance misriqiya

The International Journal of African-Egyptian Studies 
rates, especially for its girls (E.O. Akubor, 2015:12).This has been specifically noted by the Justice, Development, Peace Committee/ Caritas (2010:27-28), when it observed thus;

The second-class status of the girl child is further worsened by the poverty and deprivations of all kinds. The poverty index in Nigeria is 1,200 US Dollars GDP per capita which when compared with South Africa at US Dollar 11, 035 GDP per capita means Nigeria is in the bar of extreme poverty. Faced with insurmountable economic problems, it Is often the girl child in the family who becomes the victim. She is the one who is made to drop out of school for the benefit of her brother. She is exposed to child labour in order to support the family by going out to work, caring for the elderly or the young ones, doing domestic or farm work, or hawking. She is not given any skills and remains unskilled for most of her life. Mostly shipped out to the cities, the girls become victims of exploitative employers or human traffickers. The larger number of girls (sometimes underage), who are working as domestic $\mathrm{s}$ in the urban areas or in Europe as prostitutes are significant proof to this.

Presently Nigerian women and girls are taken to Europe, especially to Italy and Russia, and to the Middle East and North Africa, for forced prostitution. Traffickers sometimes move their victims to Europe by caravan, forcing them to cross the desert on foot, and subjecting them to forced prostitution to repay heavy debts for travel expenses (USDS, 2010). In 2010, Matthew Egbadon, then speaker of the Edo state House of Assembly made it public that he got a letter from the Nigerian ambassador to Italy stating that out of about 10,000 prostitutes in that country, 80 percent of them were from Edo State. It has also been established that over 100,000 Nigerian girls aged between 13 and 18 years are reportedly held as sex slaves in Mali. Several thousands are in the same situation in North African countries of Libya and Morocco. Same for thousands in Europe (Editorial, The Guardian, Tuesday, February, 21, 2012)

Table A: Unemployment Rates in Nigeria by Gender (March 2009) 


\begin{tabular}{|l|l|l|l|l|}
\hline $\begin{array}{l}\mathrm{s} / \mathrm{n} \\
\mathrm{o}\end{array}$ & Gender & Urban & Rural & Composite \\
\hline 1 & Male & 17.2 & 16.9 & 17 \\
\hline 2 & Female & 21.7 & 23.9 & 23.3 \\
\hline
\end{tabular}

The above table clearly shows that despite the fact that they make up $49 \%$ of the nation's total population, responsible for the reproduction of the labour force of the nation, producing $70 \%$ of the nation's food supply, they are seldom considered in term of formal employment in the society. They are often discriminated against when it comes to issue of employment, yet women have continued to contribute in other sectors especially agricultural sector, assisting in the sustainability of food security in Nigeria. This is clearly shown in Table B, as expressed in the report of the Federal Office of Statistics (1997) (cited in Sani Hajo, 2001).

Table B: Percentage Distribution of Persons Employed in Industry 1997

\begin{tabular}{|l|l|l|}
\hline Industry & Male & Female \\
\hline Agriculture & 63.0 & 47.8 \\
\hline Mining & 0.1 & 0.0 \\
\hline Manufacturing & 4.0 & 3.7 \\
\hline Utility & 1.0 & 0.0 \\
\hline Construction & 1.0 & 0.1 \\
\hline Trade & 12.0 & 37.6 \\
\hline Transportation & 5.0 & 0.1 \\
\hline Finance & 0.8 & 0.3 \\
\hline Service & 14.0 & 10.2 \\
\hline Total & 100.0 & 100.0 \\
\hline & &
\end{tabular}

misriqiya

The International Journal of African-Egyptian Studies 
Also provisions are not often made to take care of the medical needs of the women. A 2008 Demographic and Health Survey (DHS) found that for 25\% live births, only $5 \%$ were attended by nurses or midwife, and $9 \%$ by a doctor. Correspondingly, $35 \%$ of live births took place at a health facility. Women living in urban areas were much more likely to be attended to by health care specialists than those living in rural areas (65\% and $28 \%$ respectively in 2008). This imbalance in access to specialist care between urban and rural areas has been evident in all DHS surveys in Nigeria since 1990, but the gap has not narrowed over time. And as usual, the disparities between the North and South are wide, indicating that State Governors and Local Government chairmen in the North have a lot more to do, and must wake up and invest more to prevent the avoidable deaths of mothers, infants and many children under the age 5 (Nasir , 2011). According to the United Nations Population Fund, in 2010 the maternal mortality rate per 100,000 births for Nigeria is 840 compared with 608 and 473 in 2008 and 1990 respectively, while the United Nations declaration holds that over 800,000 women have VVF (a virginal problem). So more and more of our pregnant mothers are dying during labour. The under-5 mortality rate, per 1,000 births is 143. These are mostly caused by inadequate access to quality care in rural and remote areas and shortage of midwives. In fact the workforce requirement to attain $95 \%$ skilled birth attendance by 2015 is estimated to be 6,790 according to the World Midwifery's Report for 2011 compared to South Africa's requirement of just 710 .

Although the government had esrlier declared in Article 13 of the Convention on the Elimination of all forms of Discrimination against Women that state parties shall take all appropriate measures to eliminate discrimination against women in other areas of economic and social life in order to ensure, on a basis of equality of men and women, the same right; this still remains as lip service since the society is not doing anything concrete about this. For example, despite women contribution in socio-economic development, Section 55(1) of Penal Code applicable in the northern states of Nigeria provides that "Nothing is an offence which does not amount to infliction by grievous harm upon any person and which is done by a husband for the purpose of correcting his wife". This is a violation of her right to dignity guaranteed by Section 34 of the 1999 Constitution. Also the Police Act (Cap 158) Laws of the Federation provides that a woman in

misriqiya

The International Journal of African-Egyptian Studies 
police force must seek the permission of the Commissioner of Police in her area of service before she can marry. This law does not however affect the male folks in the force. The increased number of assault especially rape case in Nigeria during the COVID 19 lockdown especially between March and April tells much about what the women go through in the country. It is estimated that during this period over 3,600 rape cases were recorded across Nigeria, while the United Nations women reported a rise in gender based Violence in Lagos, indicating a 300 percent increase between Mach and April 2020. (Iroanusi , 2020). Yet, not much has been done to check the rising wave of this crime against women. Culturally,the women are considered inferior to men; while some religion hammer on that aspect that talks of women submission to enslave these women. Politically, women are relegated to the background, denied certain political positions and in some cases labelled prostitute for joining politics. This is the case in most parts of northern Nigeria where they must not been seen or heard in public. Analyzing this situation, Fapohunda, T.M (2012), wrote:

...There are legal impediments and socio-cultural obstacles against women, especially in the rural areas where the majority of women live and are economically active. Informal sector workers most of whom are women do not benefit from minimum wage and social security provisions and have to provide for their own health and retirement needs. Many girls have been withdrawn from school to assist their mothers or guardians in informal sector activities. Many are subject to harassment and exploitation from local government and local council development authorities. A few of the women have crossed over into the formal sector, in importing, manufacturing and commerce. Women in the informal sector have sometimes had to form associations to protect their interests and mobilized traditional savings and credit schemes to offer sources of capital for themselves. The lack of savings and capital makes it difficult for women in the informal sector to expand their businesses and undertake productive employment generating activities. Also, lack of capital makes it difficult for others to become self-employed. Consequently, the productive base of women who are predominant in the informal sector and their contributions are reduced due to inaccessibility to credit;... Women are hardly given the opportunity to access financial

Misriqiya

The International Journal of African-Egyptian Studies 
resources to expand their businesses or in case of misfortune like health care or family needs. The women do not have access to borrow from the banks and big financial institutions because they do not have landed properties to use as collaterals.;... Despite government programmes aimed at reaching small-scale entrepreneurs, women as a group are often not considered for assistance.

In the area of Unemployment, the figures from the Nigeria Bureau of Statistics, shows that in 2017, specifically, during the third quarter of that year, 21.2 per cent of women within the labor force that were between the ages of 15 years and 64 years and willing, able, and actively seeking work were unemployed, compared with 16.5 per cent of men within the same period (NBS, 2017). Similarly, the 2020 figure released by The National Bureau of Statistics shows that the unemployment rate rose to 27.1 per cent in the second quarter of 2020 from the 23.1 per cent recorded in the third quarter of 2018. The figures says that "For the period under review, Q2 2020, the unemployment rate among young people (15-34 years) was 34.9 per cent, up from 29.7 per cent, while the rate of underemployment for the same age group rose to 28.2 per cent from 25.7 per cent in Q3 2018. Most of these are women and girls, who would have contributed to the meaningful development of the society (NBS 2020).

In term of participation in politics and political appointments, despite the fact that women constitute the highest number of voters, yet they have been relegated to the background. This has been the situation since the nation gained independence in 1960. Presently, statistics shows that the female population of Nigeria stands at 103 million which is $49.4 \%$ of the current population of Nigeria. In the 9th Assembly, of the 469 members elected across the 6 geopolitical zones, 6 are women, constituting only $6.5 \%$ of the Senate and $5.6 \%$ of the House of Representatives. This shows a drop of $1.48 \%$ of female representation in comparison to the 8th Assembly. Similarly, at the State Assembly level, across the 36 States of the Federation, women constitute 5.2\% of the elected lawmakers (51 women out of 990). After two decades of uninterrupted democratic governance since 1999, only 6 women have emerged as Deputy Governors (WIMBIZ 2019). Till date (2020), Nigeria is yet to produce a female Governor. The national average of the $6.7 \%$ female representation in elective and appointive

misriqiya

The International Journal of African-Egyptian Studies 
positions is far below the global average of $22.5 \%$, the Africa regional average of $23.4 \%$ and the West African Sub Regional average of $15 \%$.

The statistics above clearly shows a political atmosphere and arrangement that stifles almost $50 \%$ of its population and is a clear representation of the poor showing of women in the political sphere. The table below clearly shows that in term of political appointment, women are grossly under represented compared to the male counterparts, yet they are the ones who go out to vote on election days.

\section{Table C: Women in Political Positions in Nigeria}

\begin{tabular}{|l|l|l|l|}
\hline Elections & Male & Female & Total \\
\hline L.G Councilors & 5667 & 143 & 8810 \\
\hline Chairmanship & 765 & 9 & 774 \\
\hline $\begin{array}{l}\text { State House of } \\
\text { Assembly }\end{array}$ & 971 & 12 & 983 \\
\hline $\begin{array}{l}\text { Deputy } \\
\text { Governors }\end{array}$ & 35 & 1 & 36 \\
\hline Governors & 36 & 0 & 36 \\
\hline $\begin{array}{l}\text { House of } \\
\text { Representative }\end{array}$ & 343 & 12 & 355 \\
\hline Senate & 105 & 3 & 108 \\
\hline Vice President & 1 & 0 & 1 \\
\hline President & 1 & 0 & 1 \\
\hline
\end{tabular}

Source: Independent National Electoral Commission Report, 1999

In all the reports and tables, there are clear indications there are deliberate attempts to deprive women economically, while the state on the other hand continue to deny them certain fundamental rights. All these in the opinion of the paper are further repression against women in modern day Nigeria.

\section{Conclusion}


Although one is not claiming that all these violence were directed against the women and the girl child, but the argument is that consciously or unconsciously during the course of this, women have become objects of targets in the Nigeria society right from the colonial period. This is because they are either used as shield in time of crises or as ransom seeking implements. In the case of the Aba Women's Riot it is clear that the women conscious of the fact that excessive taxation of the male folks will direct affect their well-being decided to rise up against such course. In the case of women in the Nigeria Delta area, it is clear that the well being of the family and the nonchalant attitude of the men in the area and their quest to provide of the family have continually exposed them to danger. Also the recent attack and capture of women in Borno area of northern Nigeria by the Boko Haram Islamic Sect, holding them in captivity and using them for suicide bombing, is a gross violation of womanhood. These desecrations of the right of womanhood have continued to manifest itself in different form across the country and beyond. The situation in some other part of the country presently is such that they could neither own properties nor make decisions in some family matters. For example under customary law in the South Eastern part of Nigeria (where women fought for tax exemption), a woman cannot negotiate the purchase, sale or disposition of land in any other manner. This is completely different from the South West where a woman has right to own property in her own name. There is therefore to need for the women folks to be seen and treated as human being with dignity. Although, women oppression is a global phenomenon since capitalism or class society is universal, but in Nigeria a neo-colonial country under shackles of the imperialism and their multinational agents, the conditions of women conveniently compete for the worst in the world among other third world countries. Presently, women over the years have risen to these challenges to combat and eliminate these practices and to elevate womanhood to the pedestal of dignity and to take their pride of place in society and these situations have been tagged women liberation and women empowerment by those who do not really support the course. In order to improve the socio-political status of women in Nigeria, however within the confines of capitalism, numerous women NonGovernmental Organisations (NGO's), have sprung up. They have embarked on campaign to encourage women's participation in politics, although in reality, this campaign has not gone beyond the conference halls of hotels and pages of newspapers that is it has not actually reached the grassroots. This paper therefore misriqiya

The International Journal of African-Egyptian Studies 
advocate a more radical approach to women repression and exploitation in Nigeria.

\section{References}

Abdulrazaq, M.T. (1993). Principles and Practice of Nigerian Tax Planning and Management. Ilorin: Batay Publications Limited.

Aboribo I and Umukoro N (2007), The Conflict of Globalization and the Globalization of Conflict in the Niger Delta Area of Nigeria. Paper presented at the 7th International Conference of Nigerian Sociological Association, November, Abuja.

African Network for Environment and Economic Justice (2004) "Oil of Poverty"wwwboelnigera.org/documents/oil\%20of\%poverty20in\%20Nige r\%20delta.pdf. Assessed on 24/04/2006

Akoda Winfred (2008), "Youth, Rule of Law,Order and National Security in the Niger Delta Region since 1966" Paper presented at the Historical Society of Nigeria, October, Gombe.

Akubor E.O (2005), "The Impact of Colonialism in Nigeria, 1897-1960" Unpublished M.A, Thesis, Department of History, Ahmadu Bello University Zaria.

Akubor E O (2010) "The Travail of Women in Crises in the Niger Delta Area", Scientific and Research International Journal, (International Bibliography of the Social Sciences , Directory of Open Access Journals, $<$ http://www.doaj.org>).

Akubor, E.O (2015) Poverty and Terrorism in Northern Nigeria: Reflections and Notes on the Manipulation of the almajirai System and its implication on National Development 
Akubor, B.A and Akubor, E.O (2018), Women, Agriculture and Development of Palm oil Trade in Southern Nigeria; in Vikram Singh (ed), Interrogating Women Empowerment: The Global Experience, Satyam Law International, Ansarri, Daryaganj, New Delhi.

Ajaero C (2008), "The Men Behind the Trigger in Niger Delta" Newswatch, Vol.48, No.10, September.

Andrew R (1974) Rise up Women! Ruthledge and Kegan Paul, London and Boston.

Argyle W.J (1966), The Fon of Dahomey, Oxford Clarendon Press

Asoye S (2008)," Kidnapping For Megabuck" in The News,Vol 31, No 05, August.

Azubike Godfrey (2008) "Counting their Losses" Newswatch, Vol.48, No.10, September.

Bortolot A (2003), Idia: The First Queen Mother of Benin, Department of Arts History and Archaeology, Columbia University

Boserup Esther (1970) Women's Role in Economic Development. Allen and Unwin. London

Bedford, Fubara (2002) "Politics of the Niger Delta" in Ozo-Eson Peter and Ukoha Ukiwo (2002) (eds) Niger Delta Development commission Towards a Development Nigeria, Jos, Blueprint Jos Cass.

Byfield, Judith A. (2003) "Taxation, Women, and the Colonial State: Egba Women's Revolt." Meridians: Feminism, Race, Transnationalism, 3.2 (2003): 250-77. Web. 4 Mar. 2013.

Emrerenu, E (2015), Historical and Legal Background Of Taxation In Nigeria; retrieved from researchfaculty.com on 11/11/2015

Fapohunda, T.M (2012), Women and the Informal Sector in Nigeria: Implications for Development; British Journal of Arts and Social Sciences, ISSN: 2046misriqiya

The International Journal of African-Egyptian Studies 
9578, Vol.4 No.1 (2012) CBritishJournal Publishing, Inc. 2012, http://www.bjournal.co.uk/BJASS.aspx

Falola T (1978), The Place of Women in the Pre-Colonial Yoruba Economy; Seminar Papers, Department of History, University of Ife, Koaslabaro Press, Ile-Ife.

Federal Office of Statistics (2006) The Nigerian statistical fact sheets on Economic and Social Development, FOS, Nigeria.

Federal Office of Statistics (2003) Review of the Nigerian Economy 1997, Lagos.

Foster C. A (1985) The Sociology of Development. Case way press 1td, Ormskiri, Lancashire.

Idowu, E,B, Olodumare, God in Yoruba Belief, Longman, 1962:Chapter 2

Ifueko, O.O (2011), History Of African Tax Compliance - Nigeria As A Case Study. Leadership, Thu, 17/11/2011 - 12:11am

Independent National Electoral Commission Report, 1999

International Labour Organization (1996) World Employment. www.ilo.org/public/english bureau/inf/pkits

International Labour Organization (2006) World Employment. www.ilo.org/public/english bureau/inf/pkit

Iroanusi Queensesther, Nigeria: At least 3600 Rape Cases Recorded During Lockdown-Minister, Premium Times, 14, July, 2020, http://allafrica.com

Izehi Oriaghan (2018), A Quick Look at Women's Land and Inheritance Rights in Nigeria, The Hilton Prize Coalition. http//www.landesa.org, Accessed on August 23, 2020

Jekayinfa A (2014), The Status of the Female Citizens in the Nigerian SocioCultural Environments: Implications for Social Studies Education, http://status of African women/pdf Accessed on October 2, 2014 
Johnson-Odim, Cheryl, and Nina Emma (1997), . For Women and the Nation: Funmilayo Ransome-Kuti. N.p.: University of Illinois, 1997. Print.

Johnson S (1921), The History of the YorubaLagos, C.M.S Bookshop, Lagos.

Jurie S (2016) The Women in the Bible: Their Subordinate Position, Faith and Culture, Ibadan Dominican Studies, Dominican Institute Ibadan, Vol. 1, Issue 2, January

Koffi Anan, Speech delivered at the United Nations Conference organized for the Highs and

Lows in Gender and Policy Matters, Mimeograph, issue 2, June 1998 Lombard J (1969), “The Kingdom of Dahomey” Forde D and Kaberry P.M(ed), West African Kingdom in the $19^{\text {th }}$ Century , Oxford university Press, London

Mcalpine, Mhairi.(2013) "Women on the Left: Funmilayo Anikulapo-Kuti." International Socialist Group. N.p., 8 June 2012. Web. 4 March 2013.

NasirAE(2011 Where are the Jobs? http://elombah.com/index.php?option=com

National Bureau of Statistics (2017), Four million Nigerians became jobless this year. Punch Newspaper Nigeria, http://punchng.com/four-millionnigerians-became-jobless-this-year-nbs/

National Bureau of Statistics (2017), Nigeria's Unemployment Rate Rises To $27.1 \%$ - NBS

https://punchng.com/breaking-nigerias-unemployment-rate-rises-to-27-1-says$\underline{\text { nbs/ }}$

Nike L. Edun Adebiyi, Radical Nationalism in British West Africa, 1945-60 A dissertation submitted in partial fulfilment of the requirements for the degree of Doctor of Philosophy (History) in The University of Michigan, 2008

Oakley O (1974), The Sociology of Housework, The Pitman Press, Bath. 
Ofiabor O (2008), "Why We Won't Stop Fighting” The News, Vol. 31, No. 5, August 11.

Ogbogbo Chris (2005), "Nigeria-Niger Delta Relations 1960-1995"; Paper presented at the First

Intergroup Relations in Nigeria in the 21 st century, June 8-11th, Keffi.

Ogege O (2007), The State, Multinational Oil Companies and the Dialectics of Agitations in the Niger Delta. International Conference of Nigerian Sociological Association; November, Abuja.

Ololade O (2009), "Women of the Delta: Their Lives as Victims" The Nation, Vol. 04, No. 01219, November 21.

Olusola, Ayobami. (2013), "The Abeokuta Women's Revolt." Home. N.p., 13 April 2010. Web. 5 March 2013.

Ozo-Eson P and Ukoha U (2005) Challenges of the Niger Delta, Proceedings of a Seminar on the Niger Delta, Centre for Advanced Soil Science. Port Harcourt

Palmer H.H, Gazzette of Bornu Province in Kirk-Greene A.H.M (ed) Gazzette of the Northern Province of Nigeria, London 1972

Power, J (2006), "Using women to get rid of poverty" Punch, Sunday.

Synoptic Overview of Human Rights Violations Investigation Commission Report, 2000:45-46.

Tayo G (2007), Women, Environment and Food Production: The Challenge of the Niger Delta. Paper presented at the 7th International Conference of Nigerian Sociological Association, November, Abuja.

Thomas J (2003) Women and the Challenges of the Niger Delta. Centre for Advance

Social Sciences Port Harcourt.

misriqiya

The International Journal of African-Egyptian Studies 
Tukur M, The Role of Emirs and District Heads in the Impostion, Assessment and Collection of the Kurdin Kasa and the Jangali in the Emirates, 19031914, in Abubakar T (ed), The Essential Mahmud Tukur: Selected Writings, A.B.U Press, Zaria.

U.S. Department of State (2010) Nigeria: Trafficking in Persons Report, June 14, 2010

Women in Management, Business and Public Service (WIMBIZ) 18th Annual Conference - Nov 7-8, 2019 